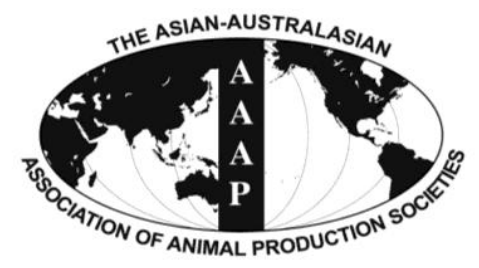

Asian-Aust. J. Anim. Sci.

Vol. 25, No. 12 : 1768-1774 December 2012

http://dx.doi.org/10.5713/ajas.2012.12418

www.ajas.info

pISSN 1011-2367 elSSN 1976-5517

\title{
Methane and Nitrous Oxide Emissions from Livestock Agriculture in 16 Local Administrative Districts of Korea
}

\author{
Eun Sook Ji and Kyu-Hyun Park* \\ National Institute of Animal Science, RDA, Suwon, Gyeonggi, 441-706, Korea
}

\begin{abstract}
This study was conducted to evaluate methane $\left(\mathrm{CH}_{4}\right)$ and nitrous oxide $\left(\mathrm{N}_{2} \mathrm{O}\right)$ emissions from livestock agriculture in 16 local administrative districts of Korea from 1990 to 2030. National Inventory Report used 3 yr averaged livestock population but this study used $1 \mathrm{yr}$ livestock population to find yearly emission fluctuations. Extrapolation of the livestock population from 1990 to 2009 was used to forecast future livestock population from 2010 to 2030. Past (yr 1990 to 2009) and forecasted (yr 2010 to 2030) averaged enteric $\mathrm{CH}_{4}$ emissions and $\mathrm{CH}_{4}$ and $\mathrm{N}_{2} \mathrm{O}$ emissions from manure treatment were estimated. In the section of enteric fermentation, forecasted average $\mathrm{CH}_{4}$ emissions from 16 local administrative districts were estimated to increase by $4 \%-114 \%$ compared to that of the past except for Daejeon (-63\%), Seoul (-36\%) and Gyeonggi (-7\%). As for manure treatment, forecasted average $\mathrm{CH}_{4}$ emissions from the 16 local administrative districts were estimated to increase by $3 \%-124 \%$ compared to past average except for Daejeon (-77\%), Busan (-60\%), Gwangju (-48\%) and Seoul (-8\%). For manure treatment, forecasted average $\mathrm{N}_{2} \mathrm{O}$ emissions from the 16 local administrative districts were estimated to increase by 10\%-153\% compared to past average $\mathrm{CH}_{4}$ emissions except for Daejeon (-60\%), Seoul (-4.0\%), and Gwangju (-0.2\%). With the carbon dioxide equivalent emissions $\left(\mathrm{CO}_{2}\right.$-Eq), forecasted average $\mathrm{CO}_{2}$-Eq from the 16 local administrative districts were estimated to increase by 31\%-120\% compared to past average $\mathrm{CH}_{4}$ emissions except Daejeon (-65\%), Seoul (-24\%), Busan (-18\%), Gwangju (-8\%) and Gyeonggi (-1\%). The decreased $\mathrm{CO}_{2}$-Eq from 5 local administrative districts was only $34 \mathrm{kt}$, which was insignificantly small compared to increase of 2,809 kt from other 11 local administrative districts. Annual growth rates of enteric $\mathrm{CH}_{4}$ emissions, $\mathrm{CH}_{4}$ and $\mathrm{N}_{2} \mathrm{O}$ emissions from manure management in Korea from 1990 to 2009 were $1.7 \%, 2.6 \%$, and $3.2 \%$, respectively. The annual growth rate of total $\mathrm{CO}_{2}$-Eq was $2.2 \%$. Efforts by the local administrative offices to improve the accuracy of activity data are essential to improve GHG inventories. Direct measurements of GHG emissions from enteric fermentation and manure treatment systems will further enhance the accuracy of the GHG data. (Key Words: Greenhouse Gas, Methane, Nitrous Oxide, Carbon Dioxide Equivalent Emission, Climate Change)
\end{abstract}

\section{INTRODUCTION}

Livestock population in Korea has been increased with a rise in national per capita income causing propensity to consume more livestock products (Lee and Lee, 2003), which in turn has led to increase greenhouse gas (GHG) emissions from livestock agriculture. In 2009, the government of Korea announced the reduction of GHG emissions up to $30 \%$ nationwide and $5.2 \%$ in livestock agriculture with active application of reduction methods, compared to GHG emissions estimated by Business-asUsual in 2020. Key categories and emissions of GHG sources should be examined accurately in order to accomplish the GHG reduction target (Kim, 2007).

\footnotetext{
* Corresponding Author: Kyu-Hyun Park. Tel: +82-31-290-1718, Fax: +82-31-290-1731, E-mail: kpark74@korea.kr Submitted Aug. 6, 2012; Accepted Sept. 10, 2012; Revised Sept. 19, 2012
}

According to the revised 1996 Intergovernmental Panel on Climate Change (IPCC) guidelines for national greenhouse gas inventories, methane $\left(\mathrm{CH}_{4}\right)$ and nitrous oxide $\left(\mathrm{N}_{2} \mathrm{O}\right)$ are the target gases in livestock agriculture. Enteric fermentation is the source of $\mathrm{CH}_{4}$ and manure treatment is the source of $\mathrm{CH}_{4}$ and $\mathrm{N}_{2} \mathrm{O}$. Methane from enteric fermentation is the byproduct of microbes' metabolic activities in the digestive organs. Microbes in anaerobic rumen, especially, play a key role in digesting feed for ruminant, which causes higher $\mathrm{CH}_{4}$ production compared to pseudo-ruminant and monogastric livestock. Methane emissions during manure treatment are produced by microbes digesting organic matters in manure stored in anaerobic condition. Methane production from manure treatment is mainly affected by the amount of stored manure, organic matter contents in manure, and the portion of manure anaerobically decomposed. Nitrous oxide emissions during manure treatment are produced during 
decomposition of nitrogen sources in anoxic condition. Methane and $\mathrm{N}_{2} \mathrm{O}$ emissions are also affected by the location of manure treatment facilities in climate region and the duration of manure treatment (Park et al., 2006; 2011).

Quantifying GHG emissions from in regional and national livestock agriculture have been studied worldwide (Zhou et al., 2007; Aljaloud et al., 2011; Merino et al., 2011). Previous researches on GHG emissions from livestock agriculture in Korea have been focused on the quantifying $\mathrm{CH}_{4}$ emission during enteric fermentation for national inventory for $\mathrm{CH}_{4}$ (Lee and Lee, 2003), the evaluation of GHG emissions during main processes in public livestock manure treatment facilities (Lim et al., 2011), and the evaluation of GHG emissions from livestock manure and food waste co-digesting biogas facility with the life cycle assessment (Nam et al., 2008). Currently local administrative districts are interested in the characteristics of their GHG emissions and GHG mitigation measures. Hence, this study was conducted to determine the characteristics of $\mathrm{CH}_{4}$ and $\mathrm{N}_{2} \mathrm{O}$ emissions from livestock agriculture and to estimate those emissions in the past and in the future in 16 local administrative districts.

\section{MATERIALS AND METHODS}

\section{Activity data and system boundary}

Activity data and emission factors in livestock category are essential to calculate GHG emission presented by IPCC (2006). The necessary activity data needed to calculate GHG emission were found in national statistics of the year. Dairy, beef including Korean native cattle called Hanwoo, swine, chicken, goat, sheep, horse, deer, and duck were chosen for this study. Greenhouse gases were emitted by two paths, enteric fermentation and manure treatment. Methane was emitted from enteric fermentation and manure treatment, and nitrous oxide was emitted from manure treatment. It is noteworthy that the populations of goat, sheep, horse, deer, and duck between 1990 and 1992 were not found so that emissions were not calculated. Population of livestock was based on December of the year and shown in Table 1. Activity data of the distribution and the types of livestock manure treatment systems in GIR (2011) were used for 16 local administrative districts of Korea. National mean air temperature $\left(14^{\circ} \mathrm{C}\right)$ were used for the mean temperature where manure treatment systems located.

\section{Calculation of greenhouse gas emissions from 16 local administrative districts in Korea}

IPCC (2006) guideline was used to calculate GHG emissions. IPCC (1996) and GIR (2011), however, were referred if activity data were not ready for the conditions of IPCC (2006). The conditions of selection of emission factors referred to GIR (2011) are based on Tier 1 approach. According to the explanation of IPCC (2006) guideline and Korea's conditions, emission factors of North America were used for dairy and beef cattle. Emission factors of Western Europe were used for swine. Emission factors of developing countries were used for other livestock. Comparisons of GHG emissions on a $\mathrm{CO}_{2}$-Eq were estimated using a $100 \mathrm{yr}$ global warming potential of 25 for $\mathrm{CH}_{4}$ and 298 for $\mathrm{N}_{2} \mathrm{O}$ (IPCC, 2006).

In order to forecast GHG emissions from 2010 to 2030, livestock populations were extrapolated with regression calculated by Grapher (2009) based on the livestock population between 1990 and 2009. Maximum limits based on actual population records were, however, set if continuous livestock population increase was anticipated. Correlation analysis was conducted by Matlab (2008) with function command corrcoef to find the effects of major livestock species on $\mathrm{CH}_{4}$ and $\mathrm{N}_{2} \mathrm{O}$ emissions in Korea.

\section{RESULTS AND DISCUSSION}

Greenhouse gas emissions from 1990 to 2009 in 16 local

Table 1. Population of Major livestock in Korea between year 1990 and 2009

\begin{tabular}{|c|c|c|c|c|c|c|c|c|c|c|c|c|}
\hline & \multicolumn{3}{|c|}{$\begin{array}{c}\text { Beef cattle } \\
\text { (head) }\end{array}$} & \multicolumn{3}{|c|}{$\begin{array}{l}\text { Dairy } \\
\text { (head) }\end{array}$} & \multicolumn{3}{|c|}{$\begin{array}{l}\text { Swine } \\
\text { (head) }\end{array}$} & \multicolumn{3}{|c|}{$\begin{array}{c}\text { Chicken } \\
\text { (head) }\end{array}$} \\
\hline & 1990 & 2000 & 2009 & 1990 & 2000 & 2009 & 1990 & 2000 & 2009 & 1990 & 2000 & 2009 \\
\hline Seoul & 248 & 201 & 439 & 572 & 211 & 86 & 2,776 & 2,034 & 12 & 35,167 & 998 & 0 \\
\hline Gyeonggi & 162,159 & 148,844 & 265,871 & 234,742 & 204,382 & 174,191 & $1,440,611$ & $1,967,773$ & $1,830,041$ & $26,488,670$ & $26,880,825$ & $32,011,008$ \\
\hline Incheon & 1,163 & 15,026 & 19,338 & 7,892 & 7,291 & 3,563 & 32,913 & 100,367 & 46,084 & 425,914 & 504,552 & 808,602 \\
\hline Chungcheongnam & 213,643 & 230,602 & 343,916 & 65,800 & 84,861 & 83,738 & 757,363 & $1,320,661$ & $1,786,094$ & $8,765,832$ & $15,721,716$ & $26,438,696$ \\
\hline Daejeon & 7,154 & 4,346 & 4,737 & 1,706 & 293 & 0 & 17,125 & 5,821 & 2,777 & 330,515 & 209,966 & 90,000 \\
\hline Chungcheongbuk & 111,703 & 111,020 & 183,081 & 22,124 & 29,855 & 23,396 & 186,389 & 392,261 & 553,852 & $3,041,583$ & $6,732,073$ & $10,375,922$ \\
\hline Jeollabuk & 115,966 & 150,732 & 305,788 & 26,549 & 44,274 & 33,346 & 319,891 & 889,920 & $1,150,669$ & $5,672,687$ & $13,785,520$ & $20,344,929$ \\
\hline Jeollanam & 233,539 & 231,546 & 439,477 & 27,883 & 38,521 & 30,647 & 352,662 & 780,375 & 830,273 & $3,774,475$ & $11,242,879$ & $14,002,271$ \\
\hline Gwangju & 10,162 & 3,352 & 6,356 & 2,778 & 1,213 & 605 & 12,326 & 11,266 & 6,733 & 564,659 & 203,368 & 93,000 \\
\hline Gangwon & 142,474 & 106,186 & 212,362 & 20,517 & 24,340 & 17,468 & 183,782 & 357,998 & 421,307 & $3,964,021$ & $4,422,762$ & $4,673,274$ \\
\hline Gyeongsangbuk & 315,677 & 302,414 & 510,744 & 45,341 & 51,961 & 39,376 & 526,327 & 986,102 & $1,209,310$ & $11,596,528$ & $14,486,582$ & $20,024,887$ \\
\hline Daegu & 9,265 & 16,375 & 19,562 & 2,768 & 5,821 & 2,781 & 22,675 & 38,824 & 20,612 & 308,903 & 293,249 & 363,600 \\
\hline Gyeongsangnam & 259,326 & 221,540 & 268,676 & 40,058 & 41,739 & 29,112 & 547,107 & 948,462 & $1,167,616$ & $7,841,607$ & $5,940,335$ & $7,515,661$ \\
\hline Busan & 1,145 & 2,022 & 1,959 & 1,929 & 1,293 & 663 & 16,869 & 39,535 & 14,564 & 848,514 & 163,434 & 89,880 \\
\hline Ulsan & - & 24,082 & 24,207 & - & 2,096 & 980 & - & 37,325 & 35,689 & - & 658,475 & 517,690 \\
\hline Jeju & 38,030 & 21,732 & 28,192 & 3,288 & 5,557 & 4,696 & 109,192 & 335,645 & 509,270 & 804,015 & $1,300,049$ & $1,418,123$ \\
\hline
\end{tabular}


Table 2. The $\mathrm{CH}_{4}$ and $\mathrm{N}_{2} \mathrm{O}$ emissions from livestock agriculture in 16 local administrative districts of Korea from 1990 to 2009

\begin{tabular}{|c|c|c|c|c|c|c|c|c|c|c|c|c|}
\hline & \multicolumn{3}{|c|}{$\begin{array}{l}\mathrm{CH}_{4} \text { emissions from } \\
\text { enteric fermentation }(\mathrm{t} / \mathrm{yr})\end{array}$} & \multicolumn{3}{|c|}{$\begin{array}{l}\mathrm{CH}_{4} \text { emissions from } \\
\text { manure treatment }(\mathrm{t} / \mathrm{yr})\end{array}$} & \multicolumn{3}{|c|}{$\begin{array}{l}\mathrm{N}_{2} \mathrm{O} \text { emissions from } \\
\text { manure treatment }(\mathrm{t} / \mathrm{yr})\end{array}$} & \multicolumn{3}{|c|}{$\begin{array}{c}\mathrm{CO}_{2} \text {-equivalent emissions* } \\
(\mathrm{kt} / \mathrm{yr})\end{array}$} \\
\hline & 1990 & 2000 & 2009 & 1990 & 2000 & 2009 & 1990 & 2000 & 2009 & 1990 & 2000 & 2009 \\
\hline Seoul & 87 & 43 & 38 & 58 & 30 & 6 & 1 & 1 & 1 & 3 & 2 & 1 \\
\hline Gyeonggi & 39,159 & 35,934 & 38,130 & 26,498 & 29,188 & 26,515 & 683 & 769 & 817 & 1,591 & 1,606 & 1,611 \\
\hline Incheon & 1,066 & 1,873 & 1,552 & 745 & 1,293 & 633 & 15 & 40 & 30 & 43 & 79 & 55 \\
\hline Chungcheongnam & 20,421 & 24,867 & 31,242 & 10,592 & 16,622 & 20,838 & 384 & 567 & 767 & 770 & 1,047 & 1,332 \\
\hline Daejeon & 611 & 284 & 260 & 258 & 76 & 30 & 11 & 6 & 5 & 22 & 9 & 8 \\
\hline Chungcheongbuk & 8,877 & 10,386 & 13,535 & 3,031 & 5,314 & 6,477 & 147 & 225 & 313 & 296 & 399 & 517 \\
\hline Jeollabuk & 9,838 & 14,983 & 22,139 & 4,475 & 10,531 & 12,455 & 188 & 384 & 566 & 359 & 655 & 902 \\
\hline Jeollanam & 16,280 & 18,656 & 28,546 & 4,899 & 9,337 & 9,666 & 274 & 429 & 598 & 530 & 721 & 988 \\
\hline Gwangju & 893 & 351 & 428 & 288 & 181 & 107 & 14 & 8 & 8 & 29 & 14 & 14 \\
\hline Gangwon & 10,309 & 9,345 & 14,131 & 2,970 & 4,634 & 4,874 & 172 & 195 & 274 & 332 & 354 & 484 \\
\hline Gyeongsangbuk & 23,007 & 24,135 & 33,860 & 7,640 & 11,947 & 13,430 & 413 & 524 & 722 & 772 & 920 & 1,217 \\
\hline Daegu & 860 & 1,654 & 1,417 & 367 & 687 & 363 & 14 & 27 & 23 & 30 & 57 & 44 \\
\hline Gyeongsangnam & 19,412 & 18,650 & 19,776 & 7,360 & 10,749 & 11,944 & 355 & 418 & 479 & 672 & 747 & 815 \\
\hline Busan & 319 & 329 & 231 & 275 & 414 & 166 & 9 & 11 & 6 & 15 & 19 & 10 \\
\hline Ulsan & - & 1,599 & 1,481 & - & 475 & 394 & - & 30 & 29 & - & 53 & 48 \\
\hline Jeju & 2,577 & 2,487 & 3,214 & 1,163 & 3,198 & 4,627 & 54 & 94 & 142 & 95 & 149 & 209 \\
\hline Total & 153,716 & 165,576 & 209,980 & 70,619 & 104,676 & 112,525 & 2,734 & 3,728 & 4,780 & 5,559 & 6,831 & 8,255 \\
\hline $\begin{array}{l}\text { Annual growth rate } \\
(\%, 1990-2009)\end{array}$ & & 1.7 & & & 2. & & & 3. & & & 2. & \\
\hline
\end{tabular}

$* \mathrm{CO}_{2}$-equivalent emissions $=\mathrm{CH}_{4}(25)$ and $\mathrm{N}_{2} \mathrm{O}(298)$ according to 2006 IPCC GL.

\section{administrative districts of Korea}

Yearly $\mathrm{CH}_{4}$ and $\mathrm{N}_{2} \mathrm{O}$ emissions from 16 local administrative districts of Korea between 1990 and 2009 were calculated and data for 10 yearly emissions are shown in Table 2. Livestock activity data of Ulsan were included in Gyeongsangnam up to 1997 and thereafter were separated as Ulsan from Gyeongsangnam.

Yearly $\mathrm{CH}_{4}$ emissions from enteric fermentation in the 16 local administrative districts of Korea between 1990 and 2009 increased from $153,717 \mathrm{t}$ in 1990 to 231,271 t in 1996 and then decreased to $157,131 \mathrm{t}$ in 2001 and increased thereafter to $209,978 \mathrm{t}$ in 2009 . Methane emissions by enteric fermentation in Gyeonggi, the highest enteric $\mathrm{CH}_{4}$ emitter among 16 local administrative districts, recorded $44,824 \mathrm{t}$ in 1994 and decreased thereafter. Local administrative districts showing decreased $\mathrm{CH}_{4}$ emissions in 2009 compared to 1990 were Gyeonggi $(-1,029$ t, $-3 \%)$, Gwangju (-465 t, $-52 \%)$, Daejeon (-351 t, $-57 \%)$, Busan $(-88$ t, $-28 \%)$, and Seoul (-48 t, -57\%). Methane emissions from enteric fermentation in other 11 local administrative districts had increased since 1990. Correlation analysis was conducted to find the effects of major livestock species on enteric $\mathrm{CH}_{4}$ emissions in Korea (Table 3). Correlation of $\mathrm{CH}_{4}$ from beef cattle to total $\mathrm{CH}_{4}$ emissions from enteric fermentation was very high $(r=0.977)$, which was much stronger than dairy $(r=0.120)$ and swine $(r=-0.098)$. Hence, beef cattle were main contributor of enteric $\mathrm{CH}_{4}$ emissions from enteric fermentation.

Yearly $\mathrm{CH}_{4}$ emissions from manure treatment systems in 16 local administrative districts of Korea between 1990 and 2009 steadily increased from 70,620 t in 1990 to $112,525 \mathrm{t}$ in 2009 , which was $29 \%-60 \%$ less than yearly $\mathrm{CH}_{4}$ emissions from enteric fermentation. Methane emissions by manure treatment systems in Gyeonggi, the highest $\mathrm{CH}_{4}$ source of manure treatment systems among 16 local administrative districts, were between $26,281 \mathrm{t}$ and $30,767 \mathrm{t}$ from 1990 and 2009. Local administrative districts where emitted less $\mathrm{CH}_{4}$ from manure treatment systems in 2009 than in 1990 were Daejeon (-227 t, -88\%), Gwangju $(-181 \mathrm{t},-63 \%)$, Incheon $(-112 \mathrm{t},-15 \%)$, Busan $(-108 \mathrm{t}$, $-40 \%)$, Seoul (-51 t, $-90 \%)$, and Daegu (-4 t, $-1 \%)$. Other 10 local administrative districts emitted steady or more $\mathrm{CH}_{4}$ (0\%-298\%) in 2009 than in 1990 from manure treatment systems.

Table 3. Correlation analysis between major livestock species and $\mathrm{CH}_{4}$ and $\mathrm{N}_{2} \mathrm{O}$ emissions of livestock categories in Korea from 1990 to 2009

\begin{tabular}{lcccc}
\hline & Enteric $\mathrm{CH}_{4}$ & Manure related $\mathrm{CH}_{4}$ & Manure related $\mathrm{N}_{2} \mathrm{O}$ & Manure related $\mathrm{CO}_{2}$ equivalent \\
\hline Beef cattle & 0.977 & -0.119 & 0.604 & 0.143 \\
Dairy & 0.120 & -0.328 & -0.295 & -0.376 \\
Swine & -0.098 & 0.990 & 0.693 & 0.954 \\
Chicken & $\mathrm{NE}^{*}$ & 0.861 & 0.700 & 0.880 \\
Duck & $\mathrm{NE}$ & 0.923 & 0.701 & 0.918 \\
\hline
\end{tabular}

* NE = Not estimated according to IPCC (2006). 
Yearly $\mathrm{N}_{2} \mathrm{O}$ emissions from manure treatment systems in 16 local administrative districts of Korea between 1990 and 2009 increased from 2,734 t in 1990 to 4,359 t in 1997 and then decreased to $3,691 \mathrm{t}$ in 2001 and increased thereafter to $4,780 \mathrm{t}$ in 2009 . When compared to $\mathrm{N}_{2} \mathrm{O}$ emissions from manure treatment systems in 1990, $\mathrm{N}_{2} \mathrm{O}$ emissions from manure treatment systems in 2009 decreased in Deajeon (-6 t, $-58 \%$ ), Gwangju (-6 t, $-42 \%)$, Busan (-2 t, -29\%) and Seoul (-0.6 t, -53\%). Total decreased $\mathrm{CH}_{4}$ emissions of these 4 local administrative districts were, however, only $16 \mathrm{t}$. Other 12 local administrative districts emitted 2,062 $\mathrm{t}$ more $\mathrm{N}_{2} \mathrm{O}$ in 2009 than in 1990. The decreased $\mathrm{N}_{2} \mathrm{O}$ emissions were only $0.7 \%$ of the increased $\mathrm{N}_{2} \mathrm{O}$ emissions, which made the decrease insignificant. With conversion of $\mathrm{CH}_{4}$ and $\mathrm{N}_{2} \mathrm{O}$ emissions from manure treatment systems to carbon dioxide equivalent emission $\left(\mathrm{CO}_{2}-\mathrm{Eq}\right), \mathrm{CO}_{2}-\mathrm{Eq}$ increased from 5,559 kt in 1990 to 8,120 $\mathrm{kt}$ in 1996 and then decreased to 6,733 kt in 2001 and increased thereafter to 8,254 kt in 2009.

Correlation analysis was conducted to examine the effects of major livestock species on $\mathrm{CH}_{4}$ and $\mathrm{N}_{2} \mathrm{O}$ emissions from manure treatment systems in Korea. Correlations of $\mathrm{CH}_{4}$ emissions from manure treatment system of swine, duck, and chicken to total $\mathrm{CH}_{4}$ emissions were high ( $r=0.990, r=0.923$, and $r=0.861$, respectively), which were much stronger than dairy $(r=-0.328)$ and beef cattle $(r=-0.119)$. Hence, monogastric livestock was the main contributor of $\mathrm{CH}_{4}$ emissions from manure treatment systems. Correlation coefficients of $\mathrm{N}_{2} \mathrm{O}$ emissions from beef cattle, dairy, swine, chicken, and duck to total $\mathrm{N}_{2} \mathrm{O}$ emissions from manure treatment systems were $r=0.604, r$ $=-0.295, r=0.693, r=0.700$, and $r=0.701$, respectively. Hence, major livestock except for dairy had moderate correlation with total $\mathrm{N}_{2} \mathrm{O}$ emissions. With conversion of $\mathrm{CH}_{4}$ and $\mathrm{N}_{2} \mathrm{O}$ emissions from manure treatment systems to $\mathrm{CO}_{2}-\mathrm{Eq}$, correlation coefficient of $\mathrm{CO}_{2}-\mathrm{Eq}$ from swine, duck, and chicken to total $\mathrm{CO}_{2}$-Eq emissions from manure treatment systems were $r=0.954, r=0.918$, and $r=0.880$, respectively, which were much stronger than dairy $(r=$ -0.376) and beef cattle $(r=0.143)$. Hence, monogastric livestock were main contributor of GHG emissions from manure treatment systems.

Annual growth rates of enteric $\mathrm{CH}_{4}$ emissions, $\mathrm{CH}_{4}$ and $\mathrm{N}_{2} \mathrm{O}$ emissions from manure management in Korea from 1990 to 2009 were $1.7 \%, 2.6 \%$, and $3.2 \%$, respectively. The annual growth rate of total $\mathrm{CO}_{2}$-Eq was $2.2 \%$. In Korea, annual population growth rate of beef cattle, swine, chicken and duck were $2.6 \%, 4.0 \%, 3.3 \%$ and $16.0 \%$, respectively, while annual dairy population growth rate was $-0.7 \%$. Zhou et al. (2007) reported that annual growth rates of enteric $\mathrm{CH}_{4}$ emissions, $\mathrm{CH}_{4}$ and $\mathrm{N}_{2} \mathrm{O}$ emissions from manure management in China from 1949 to 2003 were 2.2\%, 3.5\%, and $3.0 \%$, respectively. The annual growth rate of total $\mathrm{CO}_{2}-\mathrm{Eq}$ was $2.4 \%$. They found swine was the main contributor of GHG emissions followed by goat and sheep.

\section{Forecasted greenhouse gas emissions from 2010 to 2030 in 16 local administrative districts of Korea}

Yearly $\mathrm{CH}_{4}$ and $\mathrm{N}_{2} \mathrm{O}$ emissions from 16 local administrative districts of Korea between 2010 and 2030 were forecasted and every $10 \mathrm{yr}$ emission data are shown in Table 4. Yearly $\mathrm{CH}_{4}$ emissions from enteric fermentation in 16 local administrative districts of Korea between 2010 and 2030 were forecasted to increase steadily from $218,906 \mathrm{t}$ in 2010 to $254,987 \mathrm{t}$ in 2030. When compared to $\mathrm{CH}_{4}$ emissions from enteric fermentation in $2010, \mathrm{CH}_{4}$ emissions

Table 4. The forecasted $\mathrm{CH}_{4}$ and $\mathrm{N}_{2} \mathrm{O}$ emissions from livestock agriculture in 16 local administrative districts of Korea from 2010 to 2030

\begin{tabular}{|c|c|c|c|c|c|c|c|c|c|c|c|c|}
\hline & \multicolumn{3}{|c|}{$\begin{array}{c}\mathrm{CH}_{4} \text { emissions from } \\
\text { enteric fermentation }(\mathrm{t} / \mathrm{yr})\end{array}$} & \multicolumn{3}{|c|}{$\begin{array}{l}\mathrm{CH}_{4} \text { emissions from } \\
\text { manure treatment }(\mathrm{t} / \mathrm{yr})\end{array}$} & \multicolumn{3}{|c|}{$\begin{array}{l}\mathrm{N}_{2} \mathrm{O} \text { emissions from } \\
\text { manure treatment }(\mathrm{t} / \mathrm{yr})\end{array}$} & \multicolumn{3}{|c|}{$\begin{array}{c}\mathrm{CO}_{2} \text {-equivalent emissions* } \\
(\mathrm{kt} / \mathrm{yr})\end{array}$} \\
\hline & 2010 & 2020 & 2030 & 2010 & 2020 & 2030 & 2010 & 2020 & 2030 & 2010 & 2020 & 2030 \\
\hline $\begin{array}{l}\text { Seoul } \\
\end{array}$ & 39 & 35 & 34 & 26 & 25 & 26 & 1 & 1 & 1 & 2 & 2 & 2 \\
\hline Gyeonggi & 38,301 & 35,778 & 31,376 & 30,640 & 28,874 & 26,970 & 861 & 848 & 809 & 1,715 & 1,620 & 1,476 \\
\hline Incheon & 1,773 & 2,190 & 2,625 & 1,022 & 1,060 & 1,093 & 39 & 47 & 56 & 71 & 83 & 95 \\
\hline Chungcheongnam & 31,810 & 37,104 & 38,035 & 21,704 & 26,573 & 31,602 & 780 & 1,000 & 1,208 & 1,366 & 1,647 & 1,837 \\
\hline Daejeon & 214 & 138 & 64 & 29 & 21 & 16 & 4 & 3 & 1 & 6 & 4 & 2 \\
\hline Chungcheongbuk & 13,656 & 15,694 & 15,783 & 6,559 & 7,267 & 7,822 & 312 & 373 & 410 & 521 & 598 & 623 \\
\hline Jeollabuk & 23,150 & 26,083 & 26,509 & 12,765 & 15,312 & 17,601 & 574 & 717 & 842 & 932 & 1,092 & 1,187 \\
\hline Jeollanam & 29,639 & 33,949 & 34,101 & 10,647 & 11,713 & 12,493 & 656 & 765 & 815 & 1,049 & 1,196 & 1,231 \\
\hline Gwangju & 398 & 520 & 654 & 118 & 92 & 74 & 8 & 10 & 11 & 13 & 16 & 19 \\
\hline Gangwon & 14,751 & 16,984 & 17,192 & 5,643 & 6,966 & 8,256 & 290 & 347 & 378 & 518 & 611 & 651 \\
\hline Gyeongsangbuk & 36,797 & 40,418 & 40,862 & 14,628 & 17,896 & 21,177 & 769 & 911 & 1,021 & 1,318 & 1,507 & 1,619 \\
\hline Daegu & 1,643 & 1,944 & 2,244 & 579 & 612 & 639 & 26 & 31 & 35 & 55 & 63 & 71 \\
\hline Gyeongsangnam & 21,211 & 28,139 & 35,139 & 13,091 & 16,175 & 19,293 & 514 & 671 & 832 & 880 & 1,139 & 1,401 \\
\hline Busan & 265 & 333 & 436 & 159 & 111 & 84 & 7 & 10 & 14 & 11 & 12 & 15 \\
\hline Ulsan & 1,589 & 2,033 & 2,485 & 513 & 524 & 535 & 32 & 39 & 46 & 54 & 66 & 78 \\
\hline Jeju & 3,669 & 5,446 & 7,449 & 4,887 & 6,692 & 8,505 & 159 & 240 & 334 & 229 & 329 & 439 \\
\hline Total & 218,905 & 246,788 & 254,988 & 123,010 & 139,913 & 156,186 & 5,032 & 6,013 & 6,813 & 8,740 & 9,985 & 10,746 \\
\hline
\end{tabular}

* $\mathrm{CO}_{2}$-equivalent emissions $=\mathrm{CH}_{4}(25)$ and $\mathrm{N}_{2} \mathrm{O}(298)$ according to 2006 IPCC GL. 
from enteric fermentation in 2030 would decrease in Gyeonggi (-6,925 t, -18\%), Daejeon (-150 t, -70\%), and Seoul (-5 t, $-13 \%)$. Methane emissions from enteric fermentation in other 13 local administrative districts would increase between $171 \mathrm{t}$ and 13,929 $\mathrm{t}$ (11\%-103\%). The largest increase in $\mathrm{CH}_{4}$ emissions from enteric fermentation would happen in Gyeonsangnam (13,929 t, 66\%).

Methane emissions from manure treatment systems in 16 local administrative districts of Korea between 2010 and 2030 were forecasted to increase from 123,010 t in 2010 to $156,185 \mathrm{t}$ in 2030 , which was $95,896 \mathrm{t}-111,775 \mathrm{t}$ (39\%$46 \%$ ) less than those from enteric fermentation. When compared to $\mathrm{CH}_{4}$ emissions from manure treatment systems in 2010, $\mathrm{CH}_{4}$ emissions from manure treatment systems in 2030 would decrease in Gyeonggi $(-3,670 \mathrm{t},-12 \%)$, Busan $(-75 \mathrm{t},-47 \%)$, Gwangju (-44 t, $-38 \%)$, Daejeon (-13 t, $-44 \%)$, and Seoul $(-0.003 \mathrm{t},-0.01 \%)$. Methane emissions from manure treatment systems in other 11 local administrative districts would increase between $22 \mathrm{t}$ and 9,898 $\mathrm{t}$ (4\%-74\%). The largest increase in $\mathrm{CH}_{4}$ emissions from manure treatment systems would happen in Chungcheongnam $(9,898 \mathrm{t}, 46 \%)$.

Nitrous oxide emissions from manure treatment systems
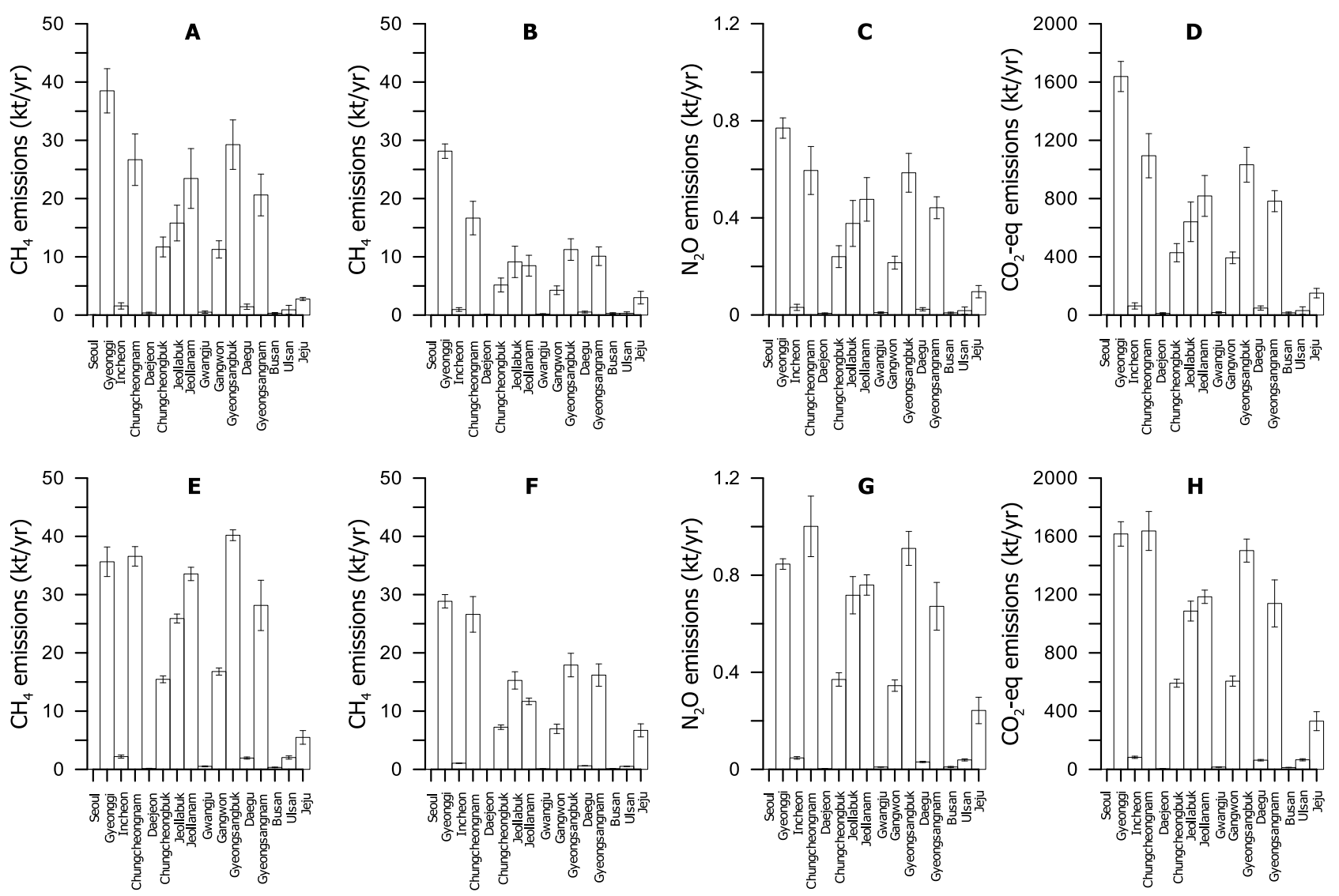

in 16 local administrative districts of Korea between 2010 and 2030 were forecasted to increase from 5,034 $\mathrm{t}$ in 2010 to $6,814 \mathrm{t}$ in 2030 . When compared to $\mathrm{N}_{2} \mathrm{O}$ emissions from manure treatment systems in $2010, \mathrm{~N}_{2} \mathrm{O}$ emissions from manure treatment systems in 2030 would decrease in Gyeonggi (-52 t, -6\%), Daejeoun (-2 t, -63\%), and Seoul $(-0.004 \mathrm{t},-0.4 \%)$. Nitrous oxide emissions from manure treatment systems in other 13 local administrative districts would increase between $3 \mathrm{t}$ and $428 \mathrm{t}$ (24\%-110\%). The largest increase in $\mathrm{N}_{2} \mathrm{O}$ emissions from manure treatment systems would happen in Chungcheongnam (428 t, 55\%) as livestock population would increase more than 3 times in 2030 than in 2010. As a result, $\mathrm{CO}_{2}$-Eq converted from $\mathrm{CH}_{4}$ and $\mathrm{N}_{2} \mathrm{O}$ emissions from enteric fermentation and manure treatment systems would increase from 8,741 kt in 2010 to $10,747 \mathrm{kt}$ in 2030.

\section{marison of mean greenhouse gas emissions from}

Comparison of mean GHG emissions from 1990 to 2009 and forecasted GHG emissions from 2010 to 2030 is shown in Figure 1. Mean $\mathrm{CH}_{4}$ emissions from enteric fermentation between 2010 and 2030 were compared to

Figure 1. The $\mathrm{CH}_{4}$ and $\mathrm{N}_{2} \mathrm{O}$ emissions from livestock agriculture between 1990 and 2009 are shown in $\mathrm{A}$ to $\mathrm{D}$. Forecasted $\mathrm{CH}_{4}$ and $\mathrm{N}_{2} \mathrm{O}$ emissions between 2010 and 2030 are shown in $\mathrm{E}$ to $\mathrm{H}$. The average $\mathrm{CH}_{4}$ emissions from enteric fermentation are shown in $\mathrm{A}$ and $\mathrm{E}$. The average $\mathrm{CH}_{4}$ emissions from manure treatment are shown in B and $\mathrm{F}$. The average $\mathrm{N}_{2} \mathrm{O}$ emissions from manure treatment are shown in $\mathrm{C}$ and $\mathrm{G}$. The average $\mathrm{CO}_{2}$-equivalent emissions are shown in $\mathrm{D}$ and $\mathrm{H}$. Vertical bars represent standard deviation. 
those between 1990 and 2009. Gyeonggi, Daejeon, and Seoul would emit 2,859 t (7\%), $232 \mathrm{t}(63 \%)$, and $20 \mathrm{t}(36 \%)$ less mean $\mathrm{CH}_{4}$ emissions from enteric fermentation between 2010 and 2030 than between 1990 and 2009, respectively. While Gyeongsangbuk, Jeollanam and Jeollabuk would emit 10,937 t (37\%), 10,103 t (43\%), and $10,098 \mathrm{t}(64 \%)$ more mean $\mathrm{CH}_{4}$ emissions from enteric fermentation between 2010 and 2030 than between 1990 and 2009, respectively. Other 10 local administrative districts would also emit between $19 \mathrm{t}$ and 9,896 t (4\%$114 \%$ ) more mean $\mathrm{CH}_{4}$ emissions from enteric fermentation between 2010 and 2030 than between 1990 and 2009. Hence, $\mathrm{CH}_{4}$ emissions from enteric fermentation should be decreased by adapting low $\mathrm{CH}_{4}$ emission methods such as feeding low $\mathrm{CH}_{4}$ generating feed and increasing feed digestibility.

Mean $\mathrm{CH}_{4}$ emissions from manure treatment systems between 2010 and 2030 were compared to those between 1990 and 2009. Busan, Gwangju, Daejeon and Seoul would emit $173 \mathrm{t}(60 \%), 88 \mathrm{t}(48 \%), 74 \mathrm{t}(77 \%)$, and $2 \mathrm{t}(8 \%)$ less mean $\mathrm{CH}_{4}$ emissions from manure treatment systems between 2010 and 2030 than between 1990 and 2009, respectively. While Chungcheongnam, Gyeongsangbuk and Jeollabuk would emit 9,957 t (60\%), 6,655 t (59\%), and $6,141 \mathrm{t}(67 \%)$ more mean $\mathrm{CH}_{4}$ emissions from manure treatment systems between 2010 and 2030 than between 1990 and 2009, respectively. Other 9 local administrative districts would also emit between $88 \mathrm{t}$ and 6,073 t (3\%$124 \%$ ) more mean $\mathrm{CH}_{4}$ emissions from manure treatment systems between 2010 and 2030 than between 1990 and 2009.

Mean $\mathrm{N}_{2} \mathrm{O}$ emissions from manure treatment systems between 2010 and 2030 were compared to those between 1990 and 2009. Daejeon, Seoul, and Gwangju would emit 4 $\mathrm{t}(60 \%), 0.04 \mathrm{t}(4 \%)$, and $0.02 \mathrm{t}(0.2 \%)$ less mean $\mathrm{N}_{2} \mathrm{O}$ emissions from manure treatment systems between 2010 and 2030 than between 1990 and 2009, respectively. While Chungcheongnam, Jeollabuk, and Gyeongsangbuk would emit $406 \mathrm{t}(68 \%), 340 \mathrm{t}(90 \%)$, and $325 \mathrm{t}(55 \%)$ more mean $\mathrm{N}_{2} \mathrm{O}$ emissions from manure treatment systems between 2010 and 2030 than between 1990 and 2009, respectively. Other 10 local administrative districts would also emit between $1 \mathrm{t}$ and $283 \mathrm{t}(10 \%-153 \%)$ more mean $\mathrm{N}_{2} \mathrm{O}$ emissions from manure treatment systems between 2010 and 2030 than between 1990 and 2009. The largest increase of $\mathrm{CH}_{4}$ and $\mathrm{N}_{2} \mathrm{O}$ emissions from manure treatment systems would happen in Chungcheongnam. That was caused by the increase of excreted manure as livestock population forecasted to increase more than $170 \%$. Hence measures to decrease $\mathrm{CH}_{4}$ and $\mathrm{N}_{2} \mathrm{O}$ emissions from manure treatment systems should be prepared.

Mean $\mathrm{CO}_{2}$-Eq from enteric fermentation and manure treatment systems between 2010 and 2030 were compared to those between 1990 and 2009. Gyeonggi, Daejeon, Busan, Gwangju, and Seoul would emit $22 \mathrm{kt}(1 \%), 8 \mathrm{kt}$ $(65 \%), 3 \mathrm{kt}(18 \%), 1 \mathrm{kt}(8 \%)$, and $0.5 \mathrm{kt}(24 \%)$ less mean $\mathrm{CO}_{2}$-Eq between 2010 and 2030 than between 1990 and 2009, respectively. While Chungcheongnam, Gyeongsangbuk, and Jeollabuk would emit $543 \mathrm{kt}(50 \%), 470 \mathrm{kt}$ (46\%), and $447 \mathrm{kt}(70 \%)$ more mean $\mathrm{CO}_{2}$-Eq between 2010 and 2030 than between 1990 and 2009, respectively. Other 8 local administrative districts would also emit between $15 \mathrm{kt}$ and $367 \mathrm{kt}(31 \%-120 \%)$ more mean $\mathrm{CO}_{2}$-Eq between 2010 and 2030 than between 1990 and 2009. The decreased $\mathrm{CO}_{2}$-Eq from 5 local administrative districts were only $34 \mathrm{kt}$, which was insignificantly small compared to increase of 2,809 kt from other 11 local administrative districts.

\section{Measures to increase accuracy and reliability}

The most difficult task to calculate GHG emissions from 16 local administrative districts was to collect activity data, especially manure treatment systems, of 16 local administrative districts. Methane and $\mathrm{N}_{2} \mathrm{O}$ emissions from manure treatment systems depended on the location and type of manure treatment systems, and mean temperature where manure treatment systems were located, but it was hard to find official statistical data. Livestock population data was collected by national statistical system, but the high variability made the population forecast difficult.

Uncertainties of activity data such as statistics of livestock population and manure treatment system were obstacles to calculate GHG emissions accurately, so that national approach to improve statistics related to GHG inventory would be key issue. Hence, local administrative districts' effort on activity data accuracy is essential to improve GHG inventories. In addition, direct measurements of GHG emissions from enteric fermentation and manure treatment systems are indispensable.

\section{ACKNOWLEDGEMENTS}

This work was supported by the Rural Development Administration and the Korea Energy Economics Institute.

\section{REFERENCES}

Aljaloud, A. A., T. Yan and A. M. Abdukader. 2011. Development of a national methane emission inventory for domestic livestock in Saudi Arabia. Anim. Feed. Sci. Technol. 166-167: 619-627.

Grapher. 2009. Grapher 8. Golden Software Inc., Golden, CO, USA.

GIR. 2011. 2009 National Greenhouse Gas Inventory Report of Korea. Greenhouse Gas Inventory and Research Center of Korea. Seoul, Korea.

IPCC. 1996. Revised 1996 IPCC Guidelines for National Greenhouse Gas Inventories (Ed. J. T. Houghton, L. G. Meira 
Filho, B. Lim, K. Treanton, I. Mamaty, Y. Bonduki, D. J. Merino, P., E. Ramirez-Fanlo, H. Arriaga, O. del Hierro, A. Griggs and B. A. Callender). UK Meteorological Office. Brackbell, UK.

IPCC. 2006. 2006 IPCC Guidelines for National Greenhouse Gas Inventories (Ed. S. Eggelston, L. Buendia, K. Miwa, T. Ngara, and K. Tanabe). The Institute for Global Environmental Strategies. Kanagawa, Japan.

Kim, D. S. 2007. Greenhouse gas $\left(\mathrm{CH}_{4}, \mathrm{CO}_{2}, \mathrm{~N}_{2} \mathrm{O}\right)$ emissions from estuarine tidal and wetland and their characteristics. J. Korean Soc. Atmospheric Environ. 23:225-241.

Lee, H. J. and S. C. Lee. 2003. National methane inventory relevant to livestock enteric fermentation. Korean J. Anim. Sci. Technol. 45:997-1006.

Lim, B. R., G. J. Cho, Y. H. Jung, J. K. Yang and S. K. Lee. 2011. Estimation of greenhouse gas emission from livestock wastewater treatment plants. J. Korea Soc. Waste Manag. 28:175-183.

Matlab, 2008. Matlab 7.7.0.471(R2008b). the Mathworks Inc., Natick, MA, USA. Artetxe and M. Viguria. 2011. Regional inventory of methane and nitrous oxide emission from ruminant livestock in the Basque country. Anim. Feed. Sci. Technol. 166-167:628-640.

Nam, J. J., Y. M. Yoon, Y. H. Lee, K. H. So and C H. Kim. 2008. Life cycle assessment of greenhouse gas emissions from livestock and food wastes co-digestive biogas production system. Korean J. Environ. Agric. 27:406-412.

Park, K.-H., A. G. Thompson, M. Marinier, K. Clark and C. Wagner-Riddle. 2006. Greenhouse gas emissions from stored liquid swine manure in a cold climate. Atmos. Environ. 40:618-627.

Park, K. -H., J. H. Jeon, K. H. Jeon, J. H. Kwag and D. Y. Choi. 2011. Low greenhouse gas emissions during composting of solid swine manure. Anim. Feed. Sci. Technol. 166-167:550556.

Zhou, J. B., M. M. Jiang and G. Q. Chen. 2007. Estimation of methane and nitrous oxide emission from livestock and poultry in China during 1949-2003. Energy Policy 35:3759-3767. 